\title{
THE TOPICAL ISSUES OF CLINICAL PHARMACOLOGY OF CLARITHROMYCIN
}

\author{
O.Yakovleva, A.Ilchenko \\ Vinnitsa National Medical University named after N.I.Pirogov \\ Zhytomyr Regional Clinical Hospital named after A.F.Gorbachevsky
Key words: clarithromycin; indirect antibacterial effects; nonantibacterial effects; immunomodulatory effect

\begin{abstract}
Recently, as evidenced by numerous publications and surveys on the topic, the interest in clarithromycin is not reduced. This drug has a wide range of the antibacterial activity, is able to penetrate into cells and create stable and high tissue concentration exceeding the level of the drug in the blood serum. However, in recent years, more attention is paid to the study of nonantibacterial effects of clarithromycin. In modern macrolides, in particular in clarithromycin, the anti-inflammatory, immunomodulatory and mucoregulatory properties have been found. The primary mechanism of the immunomodulatory action of macrolides today is considered to be their ability to affect NF-kB-and MAPK-dependent signaling pathways of cells. Under the effect of clarithromycin the decrease in the synthesis and/ or secretion of pro-inflammatory (IL-1, -6, -8, tumour necrosis factor (TNF)) and the increase in the secretion of anti-inflammatory cytokines (IL-2, -4, -10) are observed. The effectiveness of the indirect antimicrobial action of clarithromycin is intensively studied in vitro and in vivo, and it further expands our understanding of the therapeutic possibilities of this drug.
\end{abstract}

Macrolide antibiotics are widely used due to their activity against many pathogens and the presence of a number of therapeutically beneficial nonantibacterial additional properties. Semisynthetic 14-membered macrolide clarithromycin has been successfully used in medical practice for 25 years. The synthesis of clarithromycin was performed by incorporating methoxy at position of the 6-th macrocyclic lactone ring of the erythromycin structure $[1,2,9]$.

Clarithromycin inhibits the protein synthesis in bacteria by binding to the active centre of the $50 \mathrm{~S}$ ribosomal subunit. As a result of the reversible binding and inhibiting the reactions of translocation and transpeptidation, the inhibition of formation and extension of the peptide chain occurs. Recently another ability of macrolides - to disrupt the assembly of the 50S subunit has been found. The main effect of clarithromycin is bacteriostatic, but at high concentrations and low microbial density relative to $S$. pyogenes and $S$. pneumoniae this drug can exhibit the bactericidal effect $[2,18]$.

Clarithromycin is active against many gram-positive and gram-negative bacteria, as well as against the majority of intracellular pathogens such as mycoplasma, chlamydia and mycobacteria. It is highly effective against streptococcus, pneumococcus, meningococcus, gonococcus, treponema, clostridium, listeria, corynebacteria diphtheria, anthrax bacillus, Helicobacter pylori. The effectiveness of clarithromycin against Haemophilus influenzae is due to the antibacterial activity of the basic drug metabolite (14-hydroxy clarithromycin). Many gram-negative bacteria have the natural resistance to macrolides because antibiotics do not penetrate into the cell wall. However, clarithromycin has shown a significant activity in vitro and in vivo against gram-negative pathogens, such respiratory infections as Legionella pneumophlia, Moraxella catarrhalis, Bordetella pertussis. But macrolides do not affect gram-negative bacteria of such families as Enterobacteriaceae, Pseudomonas and Acinetobacter. Clarithromycin is effective against rickettsia, the causative agents of wound infection due to animal bites, active against some anaerobes, including clostridia, bacteroides, actinomycetes, propionibacteria, anaerobic cocci $[1,2,3,9]$.

Acquired resistance of microorganisms to clarithromycin may be due to modification of the target of the antibiotic and active excretion of microbial cells (efflux). Methylation of ribosomes is the main and most studied mechanism of modification of the target. It is characteristic for Streptococcus spp., Staphylococcus spp. and is stipulated by the presence of specific genes in these bacteria- erm (erythromycin ribosome methylase) responsible for the synthesis of proteins-methylases; it results in disrupted binding of macrolide with the action target. In this case cross-resistance (the so-called MLSv-type resistance) to macrolides, lincosamides and streptogramins B is formed. Mutations in rRNA and ribosomal proteins L4, L16, L22 are the mechanism of resistance, which clinical significance has not yet been determined. Single mutations in domain $\mathrm{V}$ of rRNA are observed in S. pneumoniae, Mycobacterium spp., H. pylori, B. pertussis, they lead to the expression of resistance phenotypes MLSv and ML (resistance to macrolides and lincosamides). Mutations in the L-proteins identified in clinical strains of $S$. pneumoniae and $S$. pyogenes cause the resistance to erythromycin while preserving the sensitivity to lincosamides $[1,2,9,12]$.

Active elimination (efflux) of microbial cells is carried out with the proton pump encoded by genes mefA 
and mefE [21]. In this case only 14- and 15-membered macrolides, including clarithromycin, are eliminated; the susceptibility to 16-membered macrolides, streptogramins B and lincosamides remains unchanged. The easiest resistance to macrolides develops in such pathogens as pneumococcus, group A streptococci, Haemophilus influenzae. For example, in Taiwan in hospital strains of penicillin-resistant pneumococci the resistance to macrolides occurs in $90-95 \%$. Community-acquired Haemophilus influenzae is resistant to clarithromycin; among the children in Germany there are $1-5 \%$ of cases, and group A streptococcus is found in about $4 \%$. It is noted that the frequency of resistant strains increases every year. In this regard the use of macrolides should be rational $[2,7,9,12]$.

Clarithromycin is a macrolide that is the most resistant to hydrolysis in the acidic medium. This significantly increased its bioavailability, reduced the number of adverse events in the gastrointestinal tract (GIT) and made it practically independent of food intake. The drug is rapidly absorbed from the gastrointestinal tract, reaching the maximum concentrations in $1(250 \mathrm{mg})$ or 2 hours $(500 \mathrm{mg})-1$ and $2.41 \mathrm{mg} / \mathrm{L}$, respectively; its bioavailability after oral administration is $55 \%$. When taking different doses such indicators as $\mathrm{C}_{\max }$ and AUC increase proportionally to the dose increase. The steady state concentrations of clarithromycin in the blood are created after re-taking of 5 doses. In the stationary phase the indicators of $\mathrm{C}_{\text {max }}$ of clarithromycin are equal 1-1.5 and 2-3 $\mathrm{mg} / \mathrm{L}$ after administration of 250 or $500 \mathrm{mg}$, respectively. After re-taking of $200 \mathrm{mg}$ twice daily for 14 days the accumulation of the drug in the blood is not observed. Clarithromycin has a low degree of ionization and is soluble in lipids, and therefore, it is well distributed in various organs and tissues. The volume of distribution of clarithromycin ranges from 115 to 266 litres, and binding with the serum proteins is from 42 to $70 \%[1,3,19]$.

Approximately $1 / 2$ of the dose of clarithromycin is metabolized by microsomal liver enzymes to form the main metabolite - 14-hydroxy (R) of clarithromycin, which production is greater than that of 14-hydroxy $(\mathrm{S})$ epimer. The antibacterial activity of 14-hydroxy clarithromycin (14-hydroxy CM) is little inferior to the predecessor, so the effect of the first passage through the liver almost does not impact on its activity, and parenteral administration has only some advantages. 14-Hydroxy $\mathrm{CM}$ in vitro equals erythromycin in its activity relative to H.influenzae. A hypothesis has been put forward that there is synergy concerning Haemophilus influenzae between clarithromycin and its metabolite, 14-hydroxy CM, and therefore, the activity of clarithromycin is higher in vivo than in vitro. However, this hypothesis is confirmed by the few studies that can not serve as a convincing base. The half-life of clarithromycin after a single dose is 2.6-4.6 hours; this indicator is higher for 14-hydroxy CM - 3.9-6.6 hours. The total clearance of clarithromycin ranges from 22 to $64 \mathrm{l} / \mathrm{h}$. Urinary excretion of clarithromycin is $18-36 \%$, and 14-hydroxy CM - 9.6$12 \%$. The urine contains high concentrations of clarithromycin. Part of clarithromycin and its metabolite are excreted in faeces -6.6 and $11.3 \%$. Clarithromycin pharmacokinetics in children aged 6 months to 10 years is the same as in adults. Older people (65-84 years old) have higher $\mathrm{C}_{\max }$ of clarithromycin, 14-hydroxy KM and AUC, but their renal clearance is lower than that of people aged 18-30. In patients with severe renal impairment increase in $\mathrm{C}_{\max }$ of clarithromycin in the blood and AUC, $\mathrm{T}_{1 / 2}$ prolongation and decrease of the elimination rate constant correlated with the degree of renal failure are observed. In patients with liver disease there are no significant changes in pharmacokinetics of clarithromycin, but there are some marked changes in such indicators as $\mathrm{C}_{\max }$ and AUC of 14-hydroxy CM [1, 2, 4, 9].

The advantage of new macrolides is their ability to generate high and stable concentrations in tissues that exceed the level of the drug in the serum. It is known that clarithromycin achieves high concentrations in tissues and respiratory secretions. Peak concentrations of clarithromycin and its 14-hydroxy metabolite in the serum are lower than that of erythromycin $(1.1 \mathrm{mg} / \mathrm{L} \mathrm{com}-$ pared to $2.9 \pm 0.8 \mathrm{mg} / \mathrm{l}$, respectively). Erythromycin and clarithromycin $\mathrm{C}_{\max }$ is lower than MIC 90 for some important pathogens of respiratory tract infections, including erythromycin resistant pneumococci and H.influenzae. The concentration of clarithromycin created in various tissues, particularly in the tonsils, lungs, the prostate gland exceeds that of erythromycin, and far exceeds the concentration of the drug in the serum. The high concentration of clarithromycin in tissues, however, has a limited clinical value. This concentration was obtained in the homogenizate of solid tissues consisted mainly of the intracellular material, and their high level of concentration was due to high concentrations inside the cells. The high concentration of antibiotic inside the cells is important mainly for intracellular microorganisms, and less important in extracellular pathogens. Efficacy of macrolides relative to extracellular pathogens depends on the extracellular concentration of the antibiotic and the sensitivity of microorganisms to it. The time during which the concentration of free extracellular antibiotic exceeds the MIC value is the main factor that determines the effectiveness of macrolides [1, 2, 10, 17].

Permeability of clarithromycin increases when there is inflammation in the site. This is due to the fact that macrolides, in particular clarithromycin and azithromycin, have a special tropism to cells of the immune system. Thus, the ratio of the intracellular concentration of clarithromycin to the extracellular concentration for polymorphonuclear leukocytes is $20-38$, for mononuclear cells $-16-24$. As a result, macrophages loaded with clarithromycin during their migration transport the drug into the site of inflammation creating particularly high concentrations of the drug. It is believed that clarithromycin reaches relatively high $(20-70 \mathrm{mg} / \mathrm{L})$ concentrations in the fluid covering the epithelium (FCE), which is a complex biological fluids and inflammatory cells, and this fluid washes the terminal bronchioles and alveoles. The main difficulty in determining the antibiotic concentration in FCE is that when using the bronchoalveolar lavage, phagocytes that are present in the liquid 
are placed in the antibiotic-free medium. In this case, as a result of osmosis, any antibiotic is quickly released from phagocytes. In one of the in vitro studies it has been shown that a significant number of many antibiotics that are in phagocytes can be excreted into the surrounding liquid for 20 minutes. Taking into account the artificial efflux of the intracellular antibiotic it is likely that the concentration of clarithromycin in the secretory fluid is somewhat exaggerated, but the true value is too low to be of therapeutic value. In general, clarithromycin in relation to distribution in the body occupies the "golden mean" - a balanced intermediate position among other macrolides [1, 10, 21].

The assumption of the presence of immunomodulatory properties of macrolide antibiotics was first expressed by the Japanese researchers in the 60's of the last century. The precondition for such assumptions was the results of using erythromycin in 1991 by Tanimoto $\mathrm{H}$. in patients with diffuse panbronchiolitis, it significantly improved the survival rate of patients, including patients with the respiratory tract colonization by P.aeruginosa despite the fact that this organism was not included in the spectrum of activity of macrolides. Efficacy of treatment was associated with the nonantibacterial activity of macrolides as applicable dosage did not create bactericidal concentrations in the airways. In modern macrolides, in particular clarithromycin, the anti-inflammatory, immunomodulatory and mucoregulatory properties have been found. The primary mechanism for the immunomodulatory actions of macrolides today is considered to be their ability to affect the NF-kB- and MAPK-dependent (in particular, ERK1/2 cascade) signaling pathways of cells that are used to transfer information from the plasma membrane receptors to nuclear transcription factors. This mechanism can explain many immunomodulatory effects of macrolides, including inhibition of the mucus secretion, production of pro-inflammatory cytokines, chemotaxis and cell proliferation. Specific proteins or receptors that mediate the effects of macrolides on signaling pathways have not been identified yet $[4,17,19,22]$.

At present under immunomodulatory effects of macrolides we understand the whole spectrum of effects of these drugs on different levels of the body's immunological protection, including production of cytokines, the function of epithelial cells, etc. It should be emphasized that macrolides due to their properties are immunomodulators that activate specific immune defense mechanisms and simultaneously inhibit the excessive inflammation of the respiratory tract leading to fibrosis $[1,2,10,11]$.

Clarithromycin has the modulating effect on phagocytosis, chemotaxis, killing and apoptosis of neutrophils. The inhibition of the oxidative burst occurs, resulting in reduced formation of highly active compounds that can damage their own tissues. Decrease of synthesis and/or secretion of pro-inflammatory (IL-1, $-6,-8$, tumour necrosis factor (TNF)) and increase of secretion of proinflammatory cytokines (IL-2, -4, -10) were observed $[8,16,21]$. In 2013 A. Spyridaky with colleagues in a placebo-controlled double-blind study in patients with sepsis demonstrated reduction in TNF and IL-6 and growth of IL-10 in patients receiving clarithromycin compared to placebo. Thus, clarithromycin demonstrated ability to balance the level of pro- and anti-inflammatory interleukines [4].

In experimental models of ventilator-induced lung injury in rats it has been shown that inhibition of the nuclear factor kappa B (NFkB), which regulates gene expression of pro-inflammatory cytokines and TNF, is observed with the intravenous administration of clarithromycin. Compared to the control group the content of the serum TNF- and the oxidant status in animals treated with clarithromycin reduced significantly. The neutrophilic alveolar infiltration also decreased $[5,16,20]$.

Clarithromycin has been found to reduce bronchial hyperreactivity and exhibit a beneficial effect on the clearance of bronchial and nasal secretions. This decreases the production of mucus in patients with excessive secretions, such as diffuse panbronchiolitis [13]. There is another significant aspect of the effectiveness of clarithromycin. It is in the impact on adhesion of bacteria to the epithelium, on products by microorganisms to pathogenicity factors, on formation of bacterial biofilms and quorum-sensing $[10,13,14]$.

It is important that clarithromycin inhibits the formation of alginate biofilms created by P.aeruginosa. The probable mechanism of this action is inhibition of one of the enzymes involved in the synthesis of alginate - guanosine-D-mannose dehydrogenase. This antialginate and antibiofilm effect provides the clinical efficacy of clarithromycin in diffuse panbronchiolitis and cystic fibrosis since in the pathogenesis and clinic of these diseases the immune response caused by alginate of mucus is of substantial significance [7, 18]. For example, a 4-year intake of clarithromycin in the dose of $200 \mathrm{mg} /$ day by patients with diffuse panbronchiolitis significantly improved clinical symptoms and functional performance by the 6th month of treatment, followed by positive dynamics during the entire period of therapy. Several studies demonstrated the effectiveness of clarithromycin in bronchial asthma marked by a significant decrease in the severity of clinical symptoms, the number of eosinophils in the blood and sputum, and reduced bronchial hyperresponsiveness compared to placebo [13]. The study of Nixon L. et al. demonstrated the ability of clarithromycin prescribed to 25 patients with chronic obstructive pulmonary disease (COPD) for 2 weeks in the dose of $500 \mathrm{mg}$ twice a day to improve the respiratory function indicators and reduce the severity of clinical symptoms [15]. In the study of the dosage form with sustained release used within 7 days in 120 patients with COPD without exacerbation a significant decrease in the content of IL-8 in the sputum and reduction of its viscosity were observed $[6,22]$.

The research on Pseudomonas aeruginosa isolates in the form of biofilms obtained from patients with cystic fibrosis demonstrated a significant reduction in MIC of antipseudomonal antibacterial agents during the treatment with clarithromycin. Thus, the presence of additional features along with a high antibacterial activity provides a rapid regression of symptoms and improve- 
ment of the patients' state when treating respiratory tract infections with clarithromycin [7, 10, 21].

A group of the Japanese researchers also studied the effect of clarithromycin on the migration of fibroblasts induced by the human plasma fibronectin, and the fetal lung fibroblast contraction of the human tissue. With a chemotactic tablet it was shown that clarithromycin inhibited the migration of fibroblasts $(p<0.05)$, while other antibiotics (ampicillin, minocycline, and azithromycin macrolide) had no similar effect. The effect of clarithromycin on the migration of fibroblasts is of a dose-dependent nature. The drug also inhibits the migration of fibroblasts stimulated by the analogue of thromboxane A2. However, clarithromycin has no impact on another important function of fibroblasts - collagen gel contraction [11].

\section{CONCLUSIONS}

The results obtained have allowed to conclude that clarithromycin can be involved in the regulation of the wound healing process. The effectiveness of the indirect antimicrobial activity of clarithromycin is extensively studied in vitro and in vivo. This further expands our understanding of the therapeutic possibilities of this drug.

\section{REFERENCES}

1. Волосовеи А.П., Кривопустов С.П. Макролиды в практике современной педиатрии. - К.: Четверта хвиля, 2009. - 192 с.

2. Зузова А.П., Белькова Ю.А. // Фарматека. - 2007. - №17. - С. 22-28.

3. Фешенкко Ю.И., Ячина Л.А. // Здоров’я України. - 2008. - № 16. - C. 42-43.

4. Aikaterini Spyridaki A., Antonopoulou A., Raftogiannis M. et al. // Antimicrobial Agents and Chemotherapy. - 2012. - Vol. 56. - P. 3819-3825.

5. Amado-Rodríguez L., González-López A., López-Alonso I. et al. // Respiratory Res. - 2013. - Vol. 14. - P. $52-57$.

6. Benerjee D., Honeybourne D., Khair O.A. // Treat Respir. Med. - 2004. - Vol. 3. - P. 59-65.

7. Buyck J.M., Plésiat P., Traore H. et al. // Clinical Infectious Dis. - 2012. -Vol. 55(4). - P. 534-542.

8. Giamarellos-Bourboulis E.J., Peche J.-C., Routsi C. et al. // Clinical Infectious Dis. - 2008. - Vol. 46. P. 1157-1164.

9. Foroutana S.M., Shafaatib A., Zarghib A. et al. // Iranian J. of Pharmac. Res. - 2013. - Vol. 12. - P. 65-69.

10. Hirata K., Nishizawa H., Suzuki T. et al. // J. Gastroenterol. Hepatol. - 2010. - Vol. 25. - P. 75-79.

11. Kohyama T., Takizawa H., Yamauchi Y. et al. // Respir. Med. - 2008. - Vol. 102 (12). - P. 1769-1776.

12. Kozlov R.S., Sivaja O.V., Stratchounski L.S. 7-years monitoring of resistance of clinical S. Pneumoniae in Russia: results of prospective multicenter study (PEHASus). - Proc 45th, Washington DC ICAAC. - 2005.

13. Larissa L., Pereira D.C., Paiva R.M. et al. // BMC Microbiol. - 2012. - Vol. 12. - P. 196-199.

14. Morita Y., Tomidaand J., KawamuraY. // Antimicrobials, Resistance and Chemotherapy. - 2014. - Vol. 4. P. 422-428.

15. Nixon L.S., Boorman J., Papagiannis A.J. et al. // Respir. Med. - 2007. - Vol. 101. - P. 2409-2415.

16. Restrepo M.I., Mortensen E.M., Waterer G.W. et al. // Eur. Respir. J. - 2009. - Vol. 33. - P. $153-159$.

17. Shinahara W., Sawabuchi T., Takahashi E. et al. // PLoS ONE. - 2013. - Vol. 8 (7). - P. 124-130.

18. Tagaya E., Kondo M., Tamaoki J. et al. // Chest. - 2002. - Vol. 122. - P. 213-218.

19. Tamaoki J. // Chest. - 2004. - Vol. 125. - P. 41-51.

20. Tanabe T., Kanoh S., Tsushima K. et al. // Am. J. Respir. Cell Mol. Biol. - 2011. - Vol. 45, №5. - P. 1075-1083.

21. Walkey A.J., Wiener R.S. // Chest. - 2012. - Vol. 5. - P. 141-143.

22. Wozniak D.J., Keyser R. // Chest. - 2004. - Vol. 125. - P. 62-69.

\section{АКТУАЛЬНІ ПИТАННЯ КЛІНІЧНОЇ ФАРМАКОЛОГІЇ КЛАРИТРОМІЦИНУ \\ О.О.Яковлєва, А.Б.Ільченко}

Ключові слова: кларитроміцин; непрямі антибактеріальні ефекти; неантибактеріальні есректи; імуномодулювальний вплив

Останнім часом інтерес до кларитроміцину не зменшується, що підтверджується багаточисельними публікаціями та оглядами по цій темі. Даний препарат володіє широким профрілем антибактеріальної активності, здатен проникати в клітини і створювати високі стабільні концентрації в тканинах, що перевищують рівень препарату в сироватці крові. Проте в останні роки більше уваги приділяється вивченню неантибактеріальних ефектів кларитроміцину. У сучасних макролідів, зокрема у кларитроміцину, виявлені протизапальні, імуномодулюючі та мукорегулюючі властивості. Первинним механізмом імуномодулюючої дії макролідів на сьогоднішній день прийнято вважати їх здатність впливати на NF-kB-ma MAPK-залежні сигнальні шляхи клітин. Під впливом кларитроміцину відзначено зниження синтезу та / або 
секреції прозапальних (IL-1, -6, -8, фрактора некрозу пухлин (TNF)) і посилення секреції протизапальних цитокінів (IL-2, -4, -10). Ефрективність непрямої антимікробної дії кларитроміцину інтенсивно вивчається in vitro ma in vivo, що ще більше розширює наші уявлення про терапевтичні можливості даного препарату.

\section{АКТУАЛЬНЫЕ ВОПРОСЫ КЛИНИЧЕСКОЙ ФАРМАКОЛОГИИ КЛАРИТРОМИЦИНА О.О.Яковлева, А.Б.Ильченко \\ Ключевые слова: кларитромицин; непрямые антибактериальные эффректы;} неантибактериальные эфффекты; иммуномодулирующее влияние В последнее время интерес к кларитромицину не уменьшается, что подтверждается многочисленными публикациями и обзорами по этой теме. Данный препарат обладает широким профрилем антибактериальной активности, способен проникать в клетки и создавать высокие стабильные концентрации в тканях, превышающие уровень препарата в сыворотке крови. Однако в последние годы больше внимания уделяется изучению неантибактериальных эффректов кларитромицина. У современных макролидов, в частности у кларитромицина, обнаружены противовоспалительные, иммуномодулирующие и мукорегулирующие свойства. Первичным механизмом иммуномодулирующего действия макролидов на сегодняшний день принято считать их способность влиять на NF-kB-и MAPК-зависимые сигнальные пути клеток. Под влиянием кларитромицина отмечено снижение синтеза и / или секреции провоспалительных (IL-1, -6, -8, фрактора некроза опухолей (TNF)) и усиление секреции противовоспалительных цитокинов (IL-2, -4, -10). Эфффективность непрямого антимикробного действия кларитромицина интенсивно изучается in vitro и in vivo, что еще больше расширяет наши представления о терапевтических возможностях данного препарата. 